ISSN 1392-3196 / e-ISSN 2335-8947

Zemdirbyste-Agriculture, vol. 104, No. 3 (2017), p. 203-208

DOI 10.13080/z-a.2017.104.026

\title{
Effect of fertilizers with different chemical composition on crop yield, nitrogen uptake and leaching in a sandy loam Luvisol
}

\author{
Liudmila TRIPOLSKAJA, Almantas RAZUKAS, Gvidas SIDLAUSKAS, \\ Ingrida VERBYLIENE \\ Vokè Branch, Lithuanian Research Centre for Agriculture and Forestry \\ Žalioji a. 2, Vilnius, Lithuania \\ E-mail: liudmila.tripolskaja@voke.lzi.lt
}

\begin{abstract}
New forms of mineral fertilizers containing bioactive components or substances controlling dissolution of granules in the soil are being developed to increase their efficiency and decrease negative environmental impacts. The present study was aimed to compare the effects of different complex fertilizers and complex fertilizer containing a nitrification inhibitor DMPP (3,4-dimethylpyrazole-phosphate) on barley and potato yield and quality, and nitrogen leaching. Experiments were carried out at Voke Branch of the Lithuanian Research Centre for Agriculture and Forestry during 2012-2016. Experiments were performed in lysimetric facilities on a sandy loam Luvisol (LV) with a surface area of $1.75 \mathrm{~m}^{2}$ and a test soil layer of $0.60 \mathrm{~m}$ thickness. Experimental treatments: 1) granular simple NPK fertilizers, 2) complex fertilizer nitrogenphosphate NP 33:3, 3) complex NPK fertilizer with bioactive components Eurofertil 35 and 4) complex NPK fertilizer with a nitrification inhibitor NovaTec classic. The investigated simple NPK and complex fertilizers (nitrogenphosphate NP 33:3, Eurofertil 35 and NovaTec classic) had a similar effect on the grain yield of barley, but significantly increased $(7.7 \%, P<0.05)$ the tuber yield of potatoes. Application of the fertilizer with a nitrification inhibitor improved the quality of barley grain and potato tubers and lowered the concentration of nitrates in tubers. Compared with simple fertilizers (ammonium nitrate, granular superphosphate and potassium chloride), the application of complex fertilizers nitrogenphosphate NP 33:3, Eurofertil 35, containing bioactive substances, and NovaTec classic, supplemented with a nitrification inhibitor, affected the dynamics of nitrogen leaching during specific periods, but no significant changes were estimated for nitrogen leaching per hydrological year.
\end{abstract}

Key words: leaching, mineral fertilizer, nitrification inhibitor, nitrogen.

\section{Introduction}

The intensive use of nitrogen fertilizers in order to increase crop yield has a negative impact on various aspects of the environment: nitrate leaching from agricultural land into groundwater, nitrogen losses associated with soil erosion, gaseous nitrogen losses during denitrification and ammonium emission processes. In order to reduce the losses of nitrogen leaching from fertilizers, a variety of techniques that reduce the fertilizer solubility and increase the uptake by plants are being developed. For this purpose fertilizer granules are enriched with bioactive substances, nitrification inhibitors or other materials reducing the solubility of pellets in the soil; novel nanofertilizer technologies are being developed (Davidson, Gu, 2012; Liu, Lal, 2015).

Slow/controlled release fertilizers and fertilizers with bioactive supplements are valuable alternatives to conventional fertilizers, since the nutrients are released slowly throughout the plant growing season, therefore, increasing the efficiency of nutritional elements consumption by plants and reducing the leaching losses (Motavalli et al., 2008; Prasad, 2009). The research of
Neamţu et al. (2015) on slow/controlled release of the nutrients from fertilizers of novel forms revealed that the degree of nitrogen leaching depends on the solubility of controlled fertilizer, being $61.19 \%$ for the system with N-P-Ca nutrients, and $31.97 \%$ for the system with N-P$\mathrm{Mg}$ nutrients. Nitrogen leaching may also be reduced by application of fertilizers formulated with nitrification inhibitors, which prolong the nitrogen action ( $\mathrm{Yu}$ et al., 2007; Trenkel, 2010; Alonso-Ayuso et al., 2016). But treatments including ammonium fertilizer formulated with nitrification inhibitors produced a greater degree of soil salinization due to the presence of ammonium from the fertilizer and accumulated ammonium from the nitrification inhibition (Diez et al., 2010).

Previously, in order to reduce nitrogen leaching, nitrification inhibitors nitropirin, karbamol 3(5)-methylpyrazole (KMP), cyanoguanidine were used; these substances slow down nitrification of nitrogen fertilizers, thus substantially reducing nitrogen losses and increasing the fertilizer efficiency (Di, Cameron, 2002). Now complex fertilizers with more efficient nitrification

Please use the following format when citing the article:

Tripolskaja L., Ražukas A., Šidlauskas G., Verbylienė I. 2017. Effect of fertilizers with different chemical composition on crop yield, nitrogen uptake and leaching in a sandy loam Luvisol. Zemdirbyste-Agriculture, 104 (3): 203-208 DOI 10.13080/z-a.2017.104.026 
inhibitor DMPP (3,4-dimethylpyrazole-phosphate) are developed. They effectively inhibit the ammonia oxidation, therefore reducing the nitrate concentration in the soil and the risk of leaching (Kleineidam et al., 2011). The action of this inhibitor is observed at the period when plant requirements for nitrogen are lower, that is $4-10$ weeks after sowing. The chemical compound itself does not accumulate in the soil, does not affect the biological activity of soil; it does not leach with rainfall water (Linzmeier et al., 2001). According to Barth et al. (2008), the efficiency of inhibitor DMPP is higher when it is added to fertilizers in the form of pellets in comparison with the liquid form. Besides, in light-textured soils DMPP more efficiently inhibits the nitrification processes than in heavier textured soils (Menéndez et al., 2012).

The aim of this study was to compare the effect of different complex fertilizers (nitrogenphosphate NP 33:3 and Eurofertil 35), complex fertilizer with nitrification inhibitor DMPP NovaTec classic and simple mineral fertilizers on barley and potato yield and quality, and nitrogen leaching in a sandy loam Luvisol.

\section{Material and methods}

Experimental site. Experiments were carried out in cylindrical concrete lysimeters at Voke Branch of the Lithuanian Research Centre for Agriculture and Forestry in 2012-2016. The area of lysimeters is $1.75 \mathrm{~m}^{2}$, the test soil is sandy loam Haplic Luvisol (LVha), layer $-0.60 \mathrm{~m}$. Thickness of soil A horizon is $0.28 \mathrm{~m}$. Underneath the arable horizon, 0.32 thick B horizon was formed. The number of lysimeters is 12 . The agrochemical characteristics of the soil of $0-20 \mathrm{~cm}$ before the experiment were as follows: $\mathrm{pH}_{\mathrm{KCl}} 5.5-5.9$, available phosphorus - 295-325 mg kg-1 $\mathrm{P}_{2} \mathrm{O}_{5}$, available potassium - 126-156 mg kg-1 $\mathrm{K}_{2} \mathrm{O}, \mathrm{C}_{\text {org }}-1.21-1.26 \%$.

Experimental treatments: 1) granular simple NPK fertilizers, 2) complex fertilizer nitrogenphosphate NP 33:3, 3) complex NPK fertilizer with bioactive components Eurofertil 35 and 4) complex NPK fertilizer with nitrification inhibitor NovaTec classic.

Fertilizer characteristics. Granular simple NPK fertilizers: amomonium nitrate - nitrogen fertilizer $(34.4 \%$ $\left.\mathrm{N}: 17.2 \% \mathrm{~N}_{-} \mathrm{NO}_{3}, 17.2 \% \mathrm{~N}-\mathrm{NH}_{4}\right)$, granular superphosphate $-19.0 \% \mathrm{P}_{2} \mathrm{O}_{5}$ and potassium chloride $-60 \% \mathrm{~K}_{2} \mathrm{O}$. Complex fertilizer nitrogenphosphate (stabilized ammonium nitrate) NP 33:3 (33.0\% N: 16.0\% N-NO $\left.+17.0 \% \mathrm{~N}_{3} \mathrm{NH}_{4}\right)$ and $3.0 \% \mathrm{P}_{2} \mathrm{O}_{5}$. Stabilizers - calcium hydrogenorthophosphate and ammonium dihydrogen orthophosphate. Complex NP fertilizer Eurofertil 35 N:P 15:20 (15\% N, 20\% $\mathrm{P}_{2} \mathrm{O}_{5}, 3 \%$ $\mathrm{MgO}, 18 \% \mathrm{SO}_{3}, 4 \% \mathrm{CaO}$ and $0.5 \% \mathrm{Zn}$ ). Product containing bioactive complex Physio + Mescal (Physio+, patent No. 9707222). Complex NPK fertilizer NovaTec classic with nitrification inhibitor DMPP (3,4-dimethylpyrazolephosphate), composition: $12 \% \mathrm{~N}(5 \% \mathrm{~N}-\mathrm{NO}+7 \%$ $\mathrm{N}-\mathrm{NH}_{4}$ ), 8\% $\mathrm{P}_{2} \mathrm{O}_{5}, 16 \% \mathrm{~K}_{2} \mathrm{O}, 3 \% \mathrm{MgO}, 5 \% \mathrm{SO}_{3}$ and $0.056 \%$ DMPP.

Equal rates of active nutrient substances were applied for plant (barley, potatoes) fertilization: $120 \mathrm{~kg} \mathrm{ha}^{-1}$ $\mathrm{N}, 90 \mathrm{~kg} \mathrm{ha}^{-1} \mathrm{P}_{2} \mathrm{O}_{5}$ and $120 \mathrm{~kg} \mathrm{ha}^{-1} \mathrm{~K}_{2} \mathrm{O}$, except for treatment 4 , where, due to differences in chemical composition of the fertilizer, phosphorus amounted to $80 \mathrm{~kg} \mathrm{ha}^{-1} \mathrm{P}_{2} \mathrm{O}_{5}$, potassium $-160 \mathrm{~kg} \mathrm{ha}^{-1} \mathrm{~K}_{2} \mathrm{O}$. Fertilizer efficiency and the effect on the reduction of nitrogen leaching were tested in fields with plants of different botanical groups (cereal crops - barley, row crops - potatoes). Plant rotation in 2012-2016 was as follows: barley $\rightarrow$ barley $\rightarrow$ potatoes $\rightarrow$ potatoes. Fertilizers were incorporated prior to sowing/ planting. In 2012 and 2013, spring barley cultivar 'Aura' was cultivated in lysimeters. The seeding rate was 500 seeds per $\mathrm{m}^{2}$, in 2014-2015 potato cultivar 'Goda' was cultivated $\left(9\right.$ potatoes per $\left.1.75 \mathrm{~m}^{2}\right)$. The experiment was performed in three replications for 4 years.

Sampling and analyses of plants and leachate. Lysimetric waters. Amount of infiltrate $\left(\mathrm{L} \mathrm{m}^{-2}\right)$ was measured for each month, season of the year and hydrological year (from 1 March until 28 February of the next year). Spring (March-May), summer (JuneAugust), autumn (September-November) and winter (December-February) seasons complied with the calendar year periods. In lysimetric waters, the amount of nitrate nitrogen (by colorimetric method BS EN ISO 13395-2000) was estimated, because in sandy loam Luvisol nitrogen leaching in the form of ammonium ions is negligible. The concentration of nitrate nitrogen was estimated on a monthly basis. Weighted $\mathrm{NO}_{3}^{-}$ concentration was estimated for each month, season of the year and hydrological year. Nitrogen leaching losses $\left(\mathrm{kg} \mathrm{ha}^{-1}\right)$ were calculated as a product of the concentration of the nitrogen and the amount of infiltrate during the corresponding period.

Plants. Barley grain and straw yield (by weighing, the yield was estimated $100 \%$ dry matter), potato tuber yield and its size fractions (by weighing), 1000 grain weight (by weighing) were assessed. The concentration of nitrogen (by Kieldal method) in barley grain as well as starch in potato tubers (by the method of specific weight), and nitrate concentrations (by colorimetric method) in potato tubers were estimated. Experimental data were processed using analysis of variance $(A N O V A)$. Plant quality indicators and nitrogen leaching differences among the treatments of the experiment were assessed by the least significant difference limit $\left(\mathrm{LSD}_{05}\right)$. Standard error (SE) of nitrate concentration was calculated.

Meteorological conditions. During the years of the experiment (2012 March - 2016 February), the weather conditions were very diverse; substantial deviations from the standard climate norm (SCN) (Galvonaite et al., 2007) were observed and it influenced the development of plants and processes of atmospheric precipitation infiltration. Almost through the whole experimental period the temperature exceeded the SCN (Fig. 1). Particularly warm weather was recorded in May and June of 2013; the average air temperature exceeded the SCN by $3.9-2.7^{\circ} \mathrm{C}$; in February and April of 2014 the $\mathrm{SCN}$ was exceeded by $4.7-3.3^{\circ} \mathrm{C}$; in January, February, March and December of $2015-$ by $4.8-5.4^{\circ} \mathrm{C}$. The largest positive temperature deviation was recorded in March of 2014 - the average monthly temperature was by $6.0^{\circ} \mathrm{C}$ higher than the SCN, while the largest negative temperature deviation $\left(-3.9^{\circ} \mathrm{C}\right)-$ in March of 2013 .

Deviations in precipitation amount from the $\mathrm{SCN}$ were not regular. Two longer rainy periods could be distinguished during the research period - from October of 2012 until February of 2013 and from October of 2013 until February of 2014 - when the rainfall exceeded the SCN by $9-26 \mathrm{~mm}$. Longer dry period was recorded from June until October in 2015, when the rainfall was by $37-$ $60 \mathrm{~mm}$ lower than the SCN.

\section{Results and discussion}

Plant yield and quality. During the two years (2012-2013) of the experiment, barley grain yield was quite similar, and in lysimeters fertilized with different fertilizers it averaged $0.317-0.325 \mathrm{~kg} \mathrm{~m}^{-2}$. The lowest grain yield formed in the soil fertilized with simple fertilizers (ammonium nitrate, granular superphosphate and potassium chloride). Application of complex fertilizer containing bioactive substances (Eurofertil 35) or 


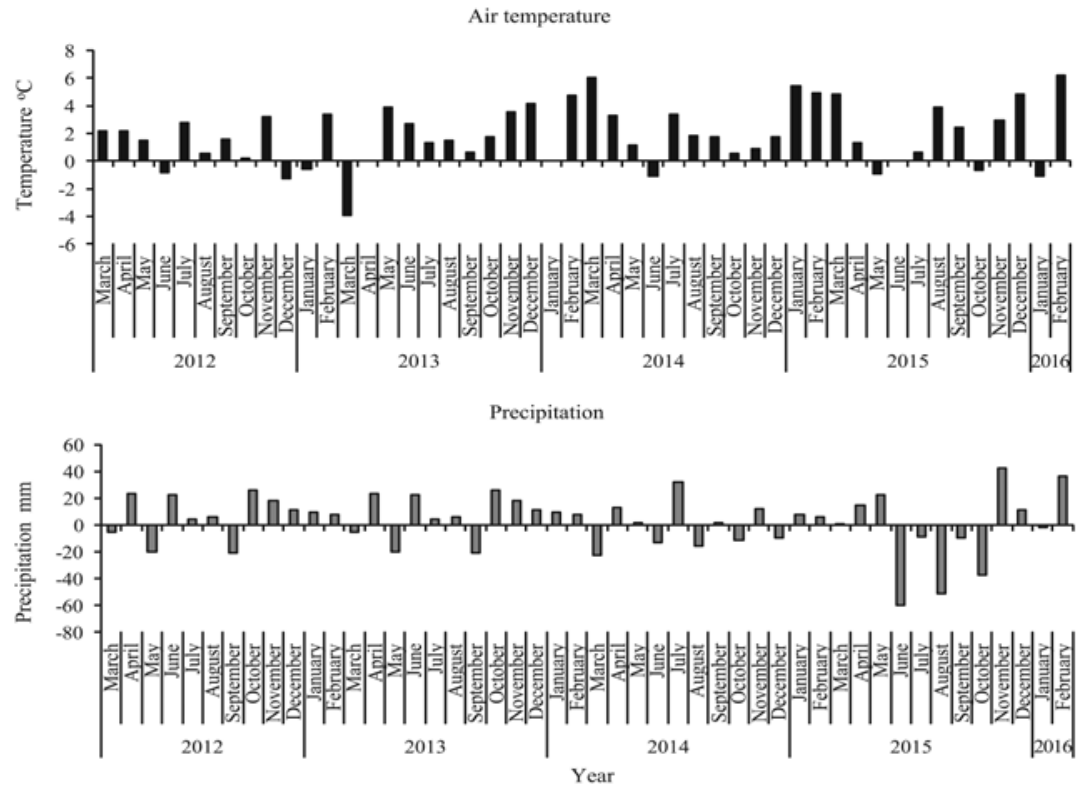

Figure 1. Deviations of air temperature and precipitation from the standard climate norm (SCN) in 2012-2016

nitrification inhibitor DMPP (NovaTec classic) increased the yield by $1.8-11.6 \%$ on average. But significant yield addition $(P<0.05)$ was obtained only after soil fertilization with fertilizer Eurofertil 35 (Table 1). The studies of Lopez et al. (2008), who have tested the impact of different rates of inhibitor DMPP on the corn yield, also showed that the DMMP additive did not increase the grain yield, as compared with urea. However, Abalos et al. (2014) suggest that the effect of inhibitor DMPP on crop yield is variable and effectiveness depends on the environmental and management factors. Application of the inhibitor DMPP resulted in the plant yield increased by $7.5-12.9 \%$. Similar data have been reported by Pasda et al. (2001). They have determined that inhibitor DMPP may increase the average crop yield (grain yield, winter wheat $+0.25 \mathrm{t} \mathrm{ha}^{-1}$, wetland rice $+0.29 \mathrm{tha}^{-1}$, grain maize $+0.24 \mathrm{t} \mathrm{ha}^{-1}$; tuber yield, potatoes $+1.9 \mathrm{tha}^{-1}$ ), reduce $\mathrm{NO}_{3}$ concentration in leafy vegetables, but has a negative effect on the crude protein concentration in winter wheat grain. The positive effect of inhibitor DMPP on crop yield was especially pronounced at sites with a high precipitation rate or intensive irrigation, and/or light sandy soil.

Table 1. The effect of fertilizers with different chemical composition on the barley yield (average for 2012-2013)

\begin{tabular}{|c|c|c|c|c|c|c|c|}
\hline \multirow[b]{2}{*}{ Fertilization treatment } & \multicolumn{3}{|c|}{ Barley grain } & \multicolumn{2}{|c|}{ Barley straw } & \multirow{2}{*}{$\begin{array}{l}\text { Straw to } \\
\text { grain } \\
\text { ratio }\end{array}$} & \multirow{2}{*}{$\begin{array}{c}\mathrm{N} \text { accumu- } \\
\text { lation in barley } \\
\mathrm{g} \mathrm{m}^{-2}\end{array}$} \\
\hline & $\mathrm{kg} \mathrm{m}^{-2}$ & $\begin{array}{l}1000 \text { grain } \\
\text { weight g }\end{array}$ & $\begin{array}{c}\mathrm{N} \\
\mathrm{mg} \mathrm{kg}^{-1}\end{array}$ & $\mathrm{~kg} \mathrm{~m}^{-2}$ & $\begin{array}{c}\mathrm{N} \\
\mathrm{mg} \mathrm{kg} \mathrm{kg}^{-1}\end{array}$ & & \\
\hline Simple NPK fertilizers & 0.306 & 38.2 & 20.8 & 0.422 & 6,1 & 1.38 & 8.07 \\
\hline Nitrogenphosphate NP 33:3 & 0.312 & 37.4 & 20.6 & 0.432 & 6.1 & 1.38 & 8.23 \\
\hline Eurofertil 35 & 0.342 & 40.5 & 19.4 & 0.459 & 5.4 & 1.34 & 7.63 \\
\hline NovaTec classic & 0.324 & 37.7 & 21.9 & 0.446 & 6.4 & 1.39 & 8.54 \\
\hline $\mathrm{LSD}_{05}$ & 0.065 & 2.49 & 1.51 & 0.073 & 1.10 & & \\
\hline
\end{tabular}

During this experiment, in two years, higher barley grain yield was obtained in the soil fertilized with fertilizer Eurofetil 35, which contains bioactive substances. In this treatment larger grains were produced -1000 grain weight was by $6.0-8.3 \%$ higher $(P<0.05)$ as compared with the effect of other fertilizers. However, after application of Eurofertil 35 the concentration of nitrogen in grain was the lowest. Similar effect of the fertilizer was observed regarding the straw yield and nitrogen concentration in the straw - higher amount of straw formed under the impact of fertilizer Eurofertil 35, but nitrogen concentration in the straw was the lowest. Still, straw to grain ratio (1.34) shows that barley plants could more effectively utilise nitrogen of Eurofertil 35 than nitrogen of other fertilizers, because the grain weight unit corresponded to a lower straw yield amount.

Potatoes were the second plant selected for testing fertilizer efficiency. Potatoes are characterized by longer growing season than barley, so plants have more time for the absorption of nitrogen from fertilizers. The experiment showed that fertilization of potatoes with simple NPK fertilizers was less effective. In this treatment, compared to complex fertilizers, the tuber yield was by $5.4-7.8 \%$ lower $(P<0.05)$, fewer large tubers (more than
$6 \mathrm{~cm}$ ) were formed, potatoes contained less starchy and accumulated more nitrates $(P<0.05)$ (Table 2$)$. Studies by Wadas and Dziugel (2013) on the effect of various complex and simple fertilizers on potato yield have also revealed that complex fertilizers, as compared with simple fertilizers, better enhance the development of the aboveground part and tubers, but of the tested complex fertilizers, only Nitrophoska Blue Special resulted in higher tuber yield, on average by $2.40 \mathrm{t} \mathrm{ha}^{-1}$, compared with simple fertilizers.

Complex fertilizers nitrogenphosphate, Eurofertil 35 and NovaTec classic equally effectively increased the tuber yield, but produced different effect on their quality. In soil fertilized with NovaTec classic, which contains nitrification inhibitor, potato tubers were most starchy and accumulated the lowest amount of nitrates. Fertilizer Eurofertil 35 gave a similar increase in tuber yield as NovaTec classic, but to a lesser extent stimulated the accumulation of starch, while the accumulated amount of nitrates was higher. Wadas (2011) stated that changes of the potato tuber quality depend on the fertilizer composition. He asserts that application of multinutrient complex fertilizers representing the nitrophoska group, that is Nitrophoska Blue Special and 
Table 2. The effect of fertilizers with different chemical composition on the potato yield (average for 2014-2015)

\begin{tabular}{lcccccc}
\hline Fertilization treatment & $\begin{array}{c}\text { Tuber yield } \\
\mathrm{kg} \mathrm{m}^{-2}\end{array}$ & $\begin{array}{c}\text { Tuber fraction } \\
>6 \mathrm{~cm} \mathrm{\%}\end{array}$ & $\begin{array}{c}\text { Starch } \\
\%\end{array}$ & $\begin{array}{c}\mathrm{N} \\
\mathrm{mg} \mathrm{kg}^{-1}\end{array}$ & $\begin{array}{c}\mathrm{NO}_{3} \\
\mathrm{mg} \mathrm{kg}^{-1}\end{array}$ & $\begin{array}{c}\mathrm{N} \text { accumulation } \\
\text { in potatoes } \\
\mathrm{g} \mathrm{m}^{-2}\end{array}$ \\
\hline Simple NPK fertilizers & 3.70 & 62.9 & 15.4 & 0.30 & 81.1 & 9.80 \\
Nitrogenphosphate & 3.90 & 66.8 & 15.5 & 0.28 & 50.1 & 9.75 \\
Eurofertil 35 & 3.99 & 68.6 & 15.6 & 0.28 & 60.6 & 10.56 \\
NovaTec classic & 3.99 & 64.8 & 16.3 & 0.29 & 49.2 & 10.61 \\
\hline \multicolumn{1}{c}{ LSD $_{05}$} & 0.249 & 8.38 & 0.370 & 0.028 & 18.4 & \\
\hline
\end{tabular}

Viking 13 , increase in total nitrogen contents in tubers. In turn, an application of HydroComplex was associated with a total nitrogen content which was similar to simple fertilizers. The studies demonstrated that a significant increase in nitrate content in tubers followed an application of the multi-nutrient complex fertilizer HydroComplex which contains most of magnesium and sulphur of all within the nitrophoska group.

Calculation of nitrogen uptake by plants demonstrated that barley plants accumulated 7.63$8.54 \mathrm{~g} \mathrm{~m}^{-2} \mathrm{~N}$, while potatoes $-9.75-10.61 \mathrm{~g} \mathrm{~m}^{-2} \mathrm{~N}$. Differences of nitrogen accumulation in plant yield under identical conditions shows that barley and potatoes utilise more nitrogen from fertilizer NovaTec classic for nutrition. In the soil fertilized with simple NPK fertilizers and nitrogenphosphate, the accumulation of nitrogen in barley and potato yields did not significantly differ, while nitrogen of the fertilizer Eurofertil 35 was better utilised by potatoes than by barley. Summarizing the data of nitrogen accumulation by plant production, it could be stated that chemical composition of fertilizers Eurofertil 35 and NovaTec classic is more favourable for plant nutrition, regarding the increasing crop yield and, accordingly, the consumption of nitrogen from fertilizers. Similar data have been published by Liu et al. (2013). According to their studies, inhibitors dicyandiamide (DCD) and DMPP added to urea increased the annual crop yield by $8.5-9.1 \%$ and $8.6-9.7 \%$, respectively, compared with the urea treatment. The application of nitrification inhibitors also tended to increase the nitrogen contents in grain $(P<0.05)$. Due to the increases in crop yield and nitrogen content of grain, the nitrogen uptake of grain and aboveground plants was by $12.8-15.8 \%$ higher.

Nitrogen leaching. Changes of nitrate concentrations in lysimetric water after fertilization shows that the leaching intensity depends on hydrothermal conditions of the season and the form of applied nitrogen fertilizer.

Under climatic conditions of Lithuania the rainfall infiltration in spring is abundant. During the experimental years, in March and April rainfall infiltration was equally intense, reaching $43-47 \%$ (52.858.6 and $50.2-54.8 \mathrm{~L} \mathrm{~m}^{-2}$ ) of the average amount of spring infiltrate, and the infiltrate in May reached only $10-11 \%$ (10.4-11.0 $\mathrm{L} \mathrm{m}^{-2}$ ). In spring, the nitrate concentrations in lysimetric waters ranged from 1.5 to $64.9 \mathrm{mg} \mathrm{kg}^{-1} \mathrm{NO}_{3}^{-}$, and the average of 2012-2016 was $25.3 \mathrm{mg} \mathrm{kg}^{-1} \mathrm{NO}_{3}^{--}$. Nitrate leaching depended not only on the hydrothermal conditions but also on the form of the applied fertilizer (Fig. 2). Data of the average nitrate concentration during spring period show that in soil fertilized with NovaTec classic, containing a nitrification inhibitor, nitrate leaching was slower, compared with other tested fertilizers, because the concentration in lysimetric water was by $4.2-7.2 \mathrm{mg} \mathrm{L}^{-1} \mathrm{NO}_{3}^{-}$lower. This means that immediately after the fertilizer introduction (second to third ten-day of April) the inhibitor DMPP was already actively inhibiting nitrification processes in soil and consequently nitrate leaching from the soil arable horizon. According to $\mathrm{Li}$

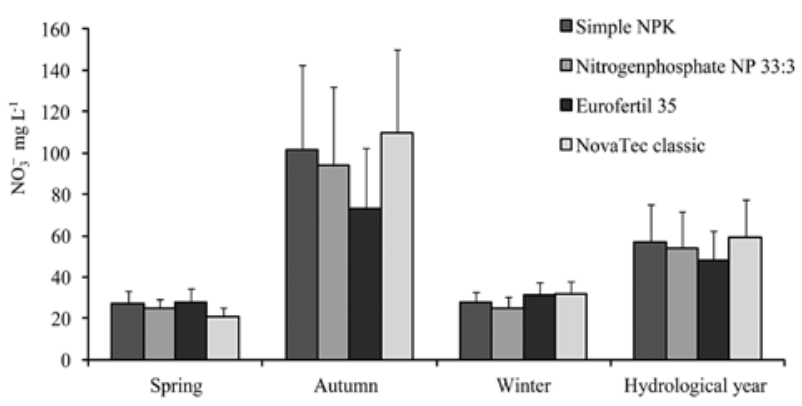

Figure 2. The effect of fertilizers with different chemical composition on nitrate concentration in lysimetric waters

et al. (2008), inhibitor DMPP enhanced the mean $\mathrm{NH}_{4}{ }^{+}-\mathrm{N}$ concentrations by $19.1 \%-24.3 \%$, but reduced the mean $\mathrm{NO}_{3}^{-}-\mathrm{N}$ concentrations by $44.9-56.6 \%$ in the leachate, under a two-year rice rape - rotation, compared to the urea alone (UA) treatment.

No differences in nitrogen leaching among the treatments of various fertilizers' application were recorded during the summer period because summers were dry throughout the period of the experiment; the air temperature was higher than the SCN and precipitation was not adequate to saturate the soil with moisture; the surplus would not form, so there was no infiltration.

In autumn, after harvesting, the mineralization of plant residues begins, and the increasing precipitation and decreasing moisture evaporation result in infiltration renewal. All this leads to quicker leaching of mineral nitrogen into the subsoil layer. Throughout the experiment, hydrothermal conditions of autumn periods were diverse. In 2012 and 2013 autumn periods were quite rainy; infiltrate amounted to $103-125 \mathrm{~L} \mathrm{~m}^{-2}$, while in 2014-2015 the precipitation was less abundant and infiltration was twice lower $-40-58 \mathrm{~L} \mathrm{~m}^{-2}$.

In autumn, the nitrate concentration ranged from $28-62 \mathrm{mg} \mathrm{L}^{-1} \mathrm{NO}^{-}$in 2012 to $103-109 \mathrm{mg} \mathrm{L}^{-1}$ $\mathrm{NO}_{3}^{-}$in 2013. Compared with the spring period, in the autumn the nitrate concentration in lysimetric waters was 2.9-5.6 times higher in all treatments. According to the average data for 2012-2015, the lowest nitrate concentration $\left(78.4 \mathrm{mg} \mathrm{L}^{-1} \mathrm{NO}_{3}^{-}\right)$was recorded in the infiltrate of soil fertilized with Eurofertil 35. In the infiltrate from soils fertilized with simple NPK fertilizers and nitrogenphosphate nitrate leaching was similar, and nitrate concentration was by $17.6-26.8 \mathrm{mg} \mathrm{L}^{-1} \mathrm{NO}_{3}^{-}$ higher, compared to soil fertilized with Eurofertil $35^{3}$. The most intensive nitrate leaching during the autumn period was recorded in the soil fertilized with NovaTec classic fertilizer containing a nitrification inhibitor. The average nitrate concentration by $8.2-50.5 \%$ exceeded the concentrations recorded in the soil fertilized with other fertilizers.

With decreasing temperature in winter, the intensity of microbiological processes slows down and, accordingly, the degradation of organic matter and nitrate formation. Temperature regime, in particular temperatures below zero, has a significant influence on 
infiltration of precipitation in winter. During the years of the experiment winters were rather diverse; in 2012, due to sub-zero temperature, the soil rapidly froze and infiltration ceased, in 2015 the infiltration was active for only a month, in 2013 and 2014 above-zero temperatures were frequent, so amounts of the infiltrate were 82-89 and 57-74 $\mathrm{L} \mathrm{m}^{-2}$, respectively. The concentration of nitrates in the infiltrate during winter period was $25-32 \mathrm{mg} \mathrm{L}^{-1}$ $\mathrm{NO}_{3}^{-}$. Differences in nitrate concentration resulting from the application of fertilizers with different chemical composition decreased, compared with the autumn period; no significant differences among the treatments were recorded.
Throughout the experimental period, the average annual nitrate concentration in different treatments was 48.2-59.3 $\mathrm{mg} \mathrm{L}^{-1} \mathrm{NO}_{3}^{-}$. Compared to simple NPK fertilizers, lower annual nitrate concentration was recorded in infiltrate of soil fertilized with Eurofertil 35 (48.2 $\mathrm{mg} \mathrm{L}^{-1} \mathrm{NO}_{3}^{-}$), while in soil fertilized with NovaTec classic it was slightly higher $\left(59.3 \mathrm{mg} \mathrm{L}^{-1} \mathrm{NO}_{3}^{-}\right)$.

Application of different form of fertilizers was changing the dynamics of nitrogen leaching in soil (Table 3 ). In spring, a month after fertilization, the nitrification inhibitor inhibited the formation of nitrates, therefore, during spring; nitrogen leaching losses in soil fertilized with NovaTec classic were by $1.58 \mathrm{~kg} \mathrm{ha}^{-1} \mathrm{~N}$

Table 3. The effect of fertilizers with different chemical composition on nitrogen leaching $\left(\mathrm{kg} \mathrm{ha}^{-1} \mathrm{~N}\right)$

\begin{tabular}{|c|c|c|c|c|c|c|}
\hline \multirow{2}{*}{ Fertilization treatment } & \multicolumn{4}{|c|}{ Seasons* } & \multicolumn{2}{|c|}{$\begin{array}{l}\text { Average of hydrological years } \\
(2012-2016)\end{array}$} \\
\hline & spring & summer & autumn & winter & $\mathrm{kg} \mathrm{ha}^{-1} \mathrm{~N}$ & $\%$ \\
\hline Simple NPK fertilisers & 7.07 & 0 & 21.89 & 3.41 & 33.05 & 100.0 \\
\hline Nitrogenphosphate NP $33: 3$ & 6.78 & 0 & 20.55 & 2.79 & 31.21 & 94.4 \\
\hline Eurofertil 35 & 7.98 & 0 & 16.03 & 3.37 & 31.28 & 94.6 \\
\hline NovaTec classic & 5.48 & 0 & 23.86 & 3.49 & 33.77 & 102.2 \\
\hline $\mathrm{LSD}_{05}$ & 1.644 & & 6.564 & 1.979 & 5.905 & \\
\hline
\end{tabular}

Note. * - during the summers of 2012-2015 no rainfall infiltration was in process.

lower, compared with ammonium nitrate and by 1.30 $2.50 \mathrm{~kg} \mathrm{ha}^{-1}$ lower, compared with nitrogenphosphate and Eurofertil 35. During autumn period, nitrogen leaching in the soil fertilized with NovaTec classic increased and exceeded the leaching from soil $(P>0.05)$ fertilized with ammonium nitrate $\left(1.97 \mathrm{~kg} \mathrm{ha}^{-1} \mathrm{~N}\right)$, nitrogenphosphate $\left(0.7 \mathrm{~kg} \mathrm{ha}^{-1} \mathrm{~N}\right)$ and Eurofertil $35\left(0.12 \mathrm{~kg} \mathrm{ha}^{-1} \mathrm{~N}\right)$.

The obtained data show that, throughout the whole period of the experiment, the average nitrogen leaching losses amounted to $31.2-33.05 \mathrm{~kg} \mathrm{ha}^{-1} \mathrm{~N}$ per year, when nitrogen fertilization rate of $120 \mathrm{~kg} \mathrm{ha}^{-1} \mathrm{~N}$ had been used. Compared to simple fertilizers, a complex fertilizer with bioactive substances Eurofertil 35 and fertilizer with a nitrification inhibitor DMPP NovaTec classic did not significantly $(P>0.05)$ reduce the nitrogen leaching losses. Olfs et al. (2005) state that in order to reduce nitrogen leaching losses, it is necessary to control the nitrogen content in plants throughout the growing season and apply multiple fertilization with nitrogen fertilizers.

\section{Conclusions}

1. Barley and potatoes more effectively utilised nitrogen from fertilizers containing bioactive substances (Eurofertil 35) and nitrification inhibitor (NovaTec classic), as compared with simple NPK fertilizer, but it caused significant increase only in potato tuber yield $(7.7 \%, P<005)$.

2. Application of fertilizer with a nitrification inhibitor improved the quality of plant production: increased nitrogen concentration in barley grain and starch accumulation in potato tubers, as well as lowered the nitrate concentration.

3. The investigated simple and complex fertilizers (nitrogenphosphate, Eurofertil 35 and NovaTec classic) equally affected the nitrogen leaching losses over a year, but the leaching dynamics over separate seasons differed. Resulting from the inhibitory action of nitrification inhibitor, in soil fertilized with NovaTec classic the nitrate leaching in spring decreased, and, compared with simple fertilizers, nitrogen phosphate and Eurofertil 35, nitrate concentration in leachate was by $4.2-7.2 \mathrm{mg} \mathrm{L}^{-1}$ $\mathrm{NO}_{3}^{-}$lower. On the contrary, in autumn in soil fertilized with NovaTec classic nitrate concentration increased, compared with other applied fertilizers.
4. If compared with simple fertilizers (ammonium nitrate, granular superphosphate and potassium chloride), application of complex fertilizers nitrogenphosphate NP 33:3 and Eurofertil 35, containing bioactive substances, and NovaTec classic, supplemented with nitrification inhibitor, for plant fertilization did not significantly change the nitrogen leaching in sandy loam Luvisol.

\section{Acknowledgements}

The paper presents research findings, obtained through the long-term research programme "Biopotential and quality of plants for multifunctional use" implemented by Lithuanian Research Centre for Agriculture and Forestry.

Received 14022017

Accepted 25052017

\section{References}

1. Alonso-Ayuso M., Gabriel J. L., Quemada M. 2016. Nitrogen use efficiency and residual effect of fertilizers with nitrification inhihitors. Furnnean Iournal of Agronomy, 80: 1-8. https://doi.org/10.1016/j.eja.2016.06.008

2. Abalos D., Jetfery S., Sanz-Cobena A., Guardia G., Vallejo A. 2014. Meta-analysis of the effect of urease and nitrification inhibitors on crop productivity and nitrogen use efficiency. Agriculture, Fonsystems and Fnvironment, 189: 136-144. https://doi.org/10.1016/j.agee.2014.03.036

3. Barth G., von Tucher S., Schmidhalter U. 2008. Effectiveness of 3,4-dimethylpyrazole phosphate as nitriflcation inhibitor in soil as influenced by inhibitor concentration, application form, and soil matric potential. Pedosnhere, 18 (3): 378-385. https://doi.org/10.1016/S1002-0160(08)60028-4

4. Davidson D., Gu F. X. 2012. Materials for sustained and controlled release of nutrients and molecules to support plant growth. Journal of Agricultural and Fond Chemistry, 60 (4): 870-876. https://doi.org/10.1021/jf204092h

5. Di H. J., Cameron K. C. 2002. The use of a nitrification inhibitor, dicyandiamide (DCD), to decrease nitrate leaching and nitrous oxide emissions in a simulated grazed and irrigated grassland. Soil I Jse and Management, 18 (4): 395-403. https://doi.org/10.1079/SUM2002151

6. Diez J. A., Arauzo M., Hernaiz P., Sanz A. 2010. The side effects of nitrification inhibitors on leaching water and soil salinization in a field experiment. Spanish Journal of Agricultural Research, 8 (1): 218-226. https://doi.org/10.5424/sjar/2010081-1161 
7. Galvonaitè A., Misiūnienė M., Valiukas D., Buitkuvienė M. S. 2007 Lithuanian climate (in Lithuanian).

8. Kleineidam K., Košmrlj K., Kublik S., Palmer I., Pfab H., Ruser R., Fiedler S., Schloter M. 2011. Influence of the nitrification inhibitor 3,4-dimethylpyrazole phosphate (DMPP) on ammonia-oxidizing bacteria and archaea in rhizosphere and bulk soil. Chemosphere. 84 (1): 182-186. https://doi.org/10.1016/j.chemosphere.2011.02.086

9. Li H., Liang X., Chen Y., Lian Y., Tian G., Ni W. 2008. Effect of nitrification inhibitor DMPP on nitrogen leaching, nitrifying organisms, and enzyme activities in a rice-oilseed rape cropping svstem. Journal of Environmental Sciences. 20 (2): 149-155. https://doi.org/10.1016/S1001-0742(08)60023-6

10. Linzmeier W., Gutser R., Schmidhalter U. 2001. Nitrous oxide emission from soil and from a nitrogen-15 labelled fertilizer with the new nitrification inhibitor 3,4-dimethylpyrazole phosphate (DAAPP). Biology and Fertility of Soils. 34 (2): 103-108. https://doi.org/10.1007/s003740100383

11. Liu R., Lal R. 2015. Potentials of engineered nanoparticles as fertilizers for increasing agronomic productions. Science of the Total Environment. 514: 131-139. https://doi.org/10.1016/j.scitotenv.2015.01.104

12. Liu C., Wang K., Zheng X. 2013. Effects of nitrification inhibitors (DCD and DMPP) on nitrous oxide emission, crop yield and nitrogen uptake in a wheat-maize cropping svstem. Biogeosciences. 10: 2427-2437. https://doi.org/10.5194/bg-10-2427-2013

13. López D., Antonio J., Pedro H. J., Mercedes A., Martín C. I. 2008. Effect of a nitrification inhibitor (DMPP) on nitrate leaching and maize yield during two growing seasons. Spanish Journal of Agricultural Research, 6 (2): 294-303. https://doi.org/10.5424/sjar/2008062-320

14. Menéndez S., Barrena I., Setien I., González-Murua C., Estavillo J. M. 2012. Efficiency of nitrification inhibitor DMPP to reduce nitrous oxide emissions under different temperature and moisture conditions. Soil Biology and Biochemistry, 53: 82-89.

https://doi.org/10.1016/j.soilbio.2012.04.026
15. Motavalli P. P., Goyne K. W., Udawatta R. P. 2008. Environmental impacts of enhanced-efficiency nitrogen fertilizers. Cron Management. 7 (1).

https://doi.org/10.1094/CM-2008-0730-02-RV

16. Neamţu C., Popescu M., Dima S.-O. 2015. Leaching and in vitro agrochemical screening for new slow release fertilizers containing N, P, Ca, and Mg. Academic Research Journal of Agricultural Science and Research, 3 (3): 45-53.

17. Olfs H.-W., Blankenau K., Brentrup F., Jasper J., Link A., Lammel J. 2005. Soil- and plant-based nitrogen-fertilizer recommendations in arable farming. Journal of Plant Nutrition and Soil Science, 168: 414-431. https://doi.org/10.1002/jpln.200520526

18. Pasda G., Hähndel R., Zerulla W. 2001. Effect of fertilizers with the new nitrification inhibitor DMPP (3,4-dimethylpyrazole phosphate) on yield and quality of agricultural and horticultural crops. Biology and Fertility of Soils. 34 (2): 85-97. https://doi.org/10.1007/s003740100381

19. Prasad R. 2009. Efficient fertilizer use: the key to food security and better environment. Journal of Tropical Agriculture, 47 (1-2): 1-17.

20. Trenkel M. E. 2010. Slow and controlled-release and stabilized fertilizers: an option for enhancing nutrient use efficiency in agriculture ( $2^{\text {nd }}$ ed.). IFA, Paris, France.

21. Wadas W. 2011. Effect of multinutrient complex fertilizers on total nitrogen and nitrate. (V) Content in the tubers of very early potato cultivars. Ecological Chemistry and Engineering, 18 (1): 123-128.

22. Wadas W., Dziugel T. 2013. Effect of multi-nutrient complex fertilizers on growth and tuber yield of very early potato (Solanum tuberosum L.) cultivars. Acta Agrobotanica. 66 (3): 55-66. https://doi.org/10.5586/aa.2013.038

23. Yu Q.-G., Chen Y.-X., Ye X.-Z., Tian G.-M., Zhang Z. J. 2007. Influence of the DMPP (3,4-dimethyl pyrazole phosphate) on nitrogen transformation and leaching in multi-laver soil columns. Chemosphere, 69 (5): 825-831. https://doi.org/10.1016/j.chemosphere.2007.05.047

ISSN 1392-3196 / e-ISSN 2335-8947

Zemdirbyste-Agriculture, vol. 104, No. 3 (2017), p. 203-208

DOI $10.13080 /$ z-a.2017.104.026

\title{
Skirtingos cheminès sudèties trąšų įtaka augalų derliui ir azoto apytakai priesmèlio dirvožemyje
}

\author{
L. Tripolskaja, A. Ražukas, G. Šidlauskas, I. Verbylienè \\ Lietuvos agrarinių ir miškų mokslų centro Vokès filialas
}

\section{Santrauka}

Siekiant padidinti mineralinių trąšų efektyvumą ir sumažinti jų neigiamą įtaką aplinkai, kuriamos naujos trąšu formos, papildytos bioakyviomis medžiagomis arba medžiagomis, kontroliuojančiomis granulių tirpumą dirvožemyje. Tyrimų tikslas - ištirti skirtingų kompleksinių trąšu ir trąšu su nitrifikacijos inhibitoriumi 3,4-dimethylpyrazolephosphatu (DMPP) efektyvumą priesmèlio išplautžemyje (ID) ir ịtaką azoto išplovimui. Eksperimentas atliktas LAMMC Vokès filiale 2012-2016 m., taikant lizimetrinių tyrimu metodą. Lizimetrų paviršiaus plotas $-1,75 \mathrm{~m}^{2}$, priesmèlio paprastojo išplautžemio sluoksnio storis $-0,60 \mathrm{~m}$. Eksperimento schema: 1) granuliuotos vienanarès mineralinès trą̧̌os, 2) azotofosfatas NP 33:3,3) kompleksine trąša su bioaktyviomis medžiagomis Eurofertil 35 ir 4) kompleksinè trąša su nitrifikacijos inhibitoriumu DMPP NovaTec classic.

Tirtu kompleksinių (azotofosfatas Np 33:3, Eurofertil 35 ir NovaTec classic) ir vienanarių NPK trąšu įtaka augalu derliui buvo skirtinga: miežių grūdų derliụ jos didino vienodai, bet bulviụ gumbų derlius dèl kompleksinių trąšu panaudojimo buvo esmingai didesnis $(7,7 \%, P<0,05)$. Nitrifikacijos inhibitorius turẻjo teigiamą ịtaką miežių grūdų ir bulvių gumbų kokybės rodikliams: padidèjo azoto ir krakmolo koncentracija, gumbų ir grūdų stambumas, sumažèjo nitratu sukaupimas gumbuose. Azoto išplovimo nuostoliai dirvožemyje, tręštame kompleksinemis trą̌somis (azotofosfatu NP 33:3, Eurofertil 35 su bioaktyviomis medžiagomis ir NovaTec classic su nitrifikacijos inhibitoriumi), palyginus su vienanarėmis trąšomis, iš esmès nesiskyrè. Dèl nitrifikacijos inhibitoriaus slopinančio poveikio nitrifikacijos procesams dirvožemyje mažèjo azoto išplovimo nuostoliai pavasario laikotarpiu, bet per hidrologinius metus jo išplovimas buvo analogiškas išplovimui iš kitų tirtų vienanaremis ir kompleksinèmis trąšomis tręštų laukelių.

Reikšminiai žodžiai: azotas, išplovimas, mineralinės trąšos, nitrifikacijos inhibitorius. 